\title{
Microbiological viability of bovine amniotic membrane stored in glycerin 99\% at room temperature for 48 months
}

\author{
Kelly Cristine de Sousa Pontes ${ }^{*}$, Camila Almeida Ramalho ${ }^{1}$, Andrea Pacheco Batista Borges ${ }^{2}$, \\ Rodrigo Viana Sepúlveda ${ }^{2}$, Renato Barros Eleotério ${ }^{2}$
}

10.1590/0034-737X201764010008

\begin{abstract}
The medium for storing biological tissues is of great importance for their optimal use in surgery. Glycerin has been proven efficient for storing diverse tissues for prolonged time, but the preservation of the bovine amniotic membrane in glycerin $99 \%$ at room temperature has never been evaluated to be used safely in surgical procedures. This study evaluated the preservation of 80 bovine amniotic membrane samples stored in glycerin $99 \%$ at room temperature. The samples were randomly divided evenly into four groups. Samples were microbiologically tested after 1, 6, 12 and 48 months of storage. The presence of bacteria and fungi in the samples was evaluated by inoculation on blood agar and incubation at $37^{\circ} \mathrm{C}$ for 48 hours and on Sabouraud agar at $25^{\circ} \mathrm{C}$ for 5 to 10 days. No fungal or bacterial growth was detected in any of the samples. It was concluded that glycerin is an efficient medium, regarding microbiology, for preserving pre-prepared bovine amniotic membrane, keeping the tissue free of microorganisms that grow in the media up to 48 months at room temperature.
\end{abstract}

Key words: biological membranes; preservation medium; surgery; amnion; caesarean section.

\section{RESUMO}

\section{Viabilidade microbiológica de membrana amniótica bovina armazenada por 48 meses em glicerina $99 \%$ em temperatura ambiente}

O meio de armazenamento dos tecidos biológicos tem grande importância para que os mesmos possam ser empregados da melhor forma em cirurgias. A glicerina tem se mostrado eficiente, considerando aspectos microbiológicos, em armazenar alguns tecidos por períodos prolongados. Porém, nunca foi avaliada a conservação da membrana amniótica bovina em glicerina $99 \%$ em temperatura ambiente para que, posteriormente, pudesse ser empregada com segurança em procedimentos cirúrgicos. Assim, foram avaliadas 80 amostras de membrana amniótica bovina armazenadas em glicerina 99\% em temperatura ambiente e divididas aleatoriamente em quatro grupos de igual número. As amostras foram submetidas à avaliação microbiológica após 1, 6, 12 e 48 meses de armazenamento. Com o objetivo de avalizar a possível presença de bactérias e fungos nas amostras, elas foram inoculadas em ágar-sangue e incubadas a $37^{\circ} \mathrm{C}$ por 48 horas e em ágar Sabouraud a $25^{\circ} \mathrm{C}$ durante 5 a 10 dias. Não houve crescimento fúngico ou bacteriano em nenhuma das amostras. Conclui-se que a glicerina é um meio de conservação eficiente, no que tange a microbiologia, de membrana amniótica bovina previamente preparada, mantendo o tecido isento de microorganismos que se multiplicam nos meios utilizados por um período de até 48 meses em temperatura ambiente.

Palavras-chave: membranas biológicas; meios de conservação; cirurgia; âmnion; operação cesariana.

Submitted on June $12^{\text {th }}, 2015$ and accepted on December $19^{\text {th }}, 2016$.

${ }^{1}$ Faculdade de Ciências Biológicas e da Saúde, Viçosa, Minas Gerais, Brazil. kellycpontes@yahoo.com.br; ramalho.vet@hotmail.com

${ }^{2}$ Universidade Federal de Viçosa, Department of Veterinary, Viçosa, Minas Gerais, Brazil. andrea@ufv.br; digosepulveda@hotmail.com; renato_ufv@hotmail.com

*Corresponding author: kellycpontes@yahoo.com.br 


\section{INTRODUCTION}

Sterility maintenance is a primary concern regardless of the method for preserving a biomaterial (Slatter \& Dietrich, 2007). Thus, a number of media have been studied for storing biological membranes and glycerin has shown good results (Okamoto et al., 2000). Glycerin has antiseptic properties, acts as fixative and dehydrating agent (Chirife et al., 1982; Amendola, 2007), is capable of preserving the ionic concentration and cellular integrity of the tissue (Pigossi, 1967), and is indicated for the preservation of numerous biological materials. Its low cost and easy handling also encourage its use as storage medium (Pigossi, 1967; Amendola, 2007; Pontes et al., 2008; Pontes et al., 2011).

On the basis of the authors' clinical and experimental experience, the amniotic membrane has already been used in the treatment of superficial and penetrating experimental corneal ulcers in rabbits (Pontes et al., 2008; Pontes et al., 2014), corneal ulcers refractory to clinical treatment in dogs, and after resection of feline corneal sequestrum (Pontes et al., 2010) and dermoid cyst in dogs (Rios et $a l .$, 2014). In veterinary medicine, it has already been used in the treatment of penetrating corneal ulcers (Barros et al., 1998), resection of corneal and scleral tumors, in symblepharon treatment (Barros et al., 2005), limbic cell deficiency (Cremonini et al., 2007), and chemical burns (Choi et al., 2011). This type of membrane can be used fresh or preserved in some type of medium. The amniotic membrane is harvested during cesarean section of term fetuses, making it impracticable to apply it fresh in surgeries without previous planning. In this context, when the amniotic membrane is necessary in a certain surgical procedure, it should be available in a tissue bank and stored in a medium that prevents bacterial and fungal growth. It is, therefore, important the creation of amniotic membrane banks. Besides, it is not difficult to acquire amniotic membranes, especially in the veterinary context, which makes it an attractive biomaterial for use in surgeries.

Currently, the use of amniotic membrane has become common in surgeries, but there are no reports in the literature on the suitability of glycerin $99 \%$ at room temperature as a microbiological conservation medium for this type of biomaterial.

Thus, the objective of this study was to evaluate the use of glycerin $99 \%$ for preserving bovine amniotic membrane at room temperature for 48 months. If its efficiency was demonstrated during this period, banks of this biomaterial could be created, allowing its use over time in several types of surgical procedures, without having to plan a caesarean section for harvesting the amniotic membrane at the time coinciding with its use in fresh.

\section{MATERIAL AND METHODS}

This research project was approved by the Research Ethics Committee of the Faculdade de Ciências Biológicas e da Saúde - FACISA/ UNIVIÇOSA, number 00113/2012.

The amniotic membrane was prepared according to the literature (Kim \& Tseng, 1995); it was harvested under sterile conditions from a pregnant female bearing a full-term fetus during elective caesarean section at the Veterinary Hospital of the Universidade Federal de Viçosa. In a surgical environment, the amniotic membrane, with the chorion, was first washed in $0.9 \%$ sterile saline solution at room temperature to remove the clots, then washed three times with sterile phosphate buffer solution containing $1000 \mathrm{IU} /$ $\mathrm{ml}$ penicillin G, $20 \mathrm{mcg} / \mathrm{ml}$ streptomycin, and $2.5 \mathrm{mcg} / \mathrm{ml}$ amphotericin B. The amnion was manually separated from the chorion (Figure 1A) (Kim \& Tseng, 1995), mounted, epithelial face upwards, onto nitrocellulose paper (Figure 1B), and cut into the size of $1.0 \mathrm{~cm}^{2}$. Subsequently, the fragment was placed in a sterile glass vial and covered with sterile glycerin 99\% (Figure 1C) (Pontes et al., 2014).

A total of 80 flasks containing amniotic membrane in glycerin $99 \%$ were randomly distributed into four equally sized groups. Each group contained 20 bovine amniotic membrane fragments and were all maintained at room temperature. Thirty days after harvest, group 1 was microbiologically tested (Barros et al., 1998, Pontes et al., 2008, Pontes et al., 2014). Group 2 was subjected to the same test after 6 months, group 3 after 12 months, and group 4 after 48 months.

Membrane fragments were aseptically collected using sterile tweezers in a laminar flow cabinet, triturated with $0.85 \%$ sterile saline solution and inoculated by surface spreading on plates containing blood agar (5\% sheep's blood) and plates containing Sabouraud dextrose agar. To isolate bacteria, the samples inoculated on blood agar and incubated at $37{ }^{\circ} \mathrm{C}$ for 48 hours and to monitor fungal growth, the samples were inoculated on Sabouraud agar at $25^{\circ} \mathrm{C}$ for 5 to 10 days (Quinn et al., 2005).

\section{RESULTS AND DISCUSSION}

Fungal growth was observed in two samples of G4. Therefore, a new microbiological analysis was performed in all the samples and none of them showed fungal or bacterial growth. This result suggests that there was contamination during the handling of the membranes in the first microbiological analysis, corroborating with Gioso et al. (2002), who found that the simple handling of bones, however careful, could introduce contaminating microorganisms into the samples.

The amniotic membrane was microbiologically evaluated only after 30 days, because according to literature, the membrane should remain for at least 30 days 
in glycerin for the loss of the ability to stimulate immune reaction to take place (Pigossi, 1967; Daleck et al. al., 1992; Costa Neto et al., 1999).

Additionally, elimination of bacteria may require up to 27 days to occur and the tissue should remain for at least 30 days in glycerin, according to a study on the effects of glycerin on tendons inoculated with gram negative and gram positive bacteria (Krauspenhar et al., 2003).

Although the amniotic membrane has been properly prepared according to the literature (Kim \& Tseng, 1995), we can attribute to glycerin $99 \%$ the absence of fungal and bacterial growth during storage of bovine amniotic membrane at room temperature for up to 48 months. This result was important, since glycerin had never been microbiologically evaluated as a medium for preserving the amniotic membrane at room temperature. Glycerin has been studied for storing pericardium (Brun et al., 2002a) and bone tissue (Gioso et al., 2002), which in the long term showed no significant growth of microorganisms.

Amniotic membrane preservation has been reported in glycerin at $4{ }^{\circ} \mathrm{C}(\mathrm{Kim} \& \mathrm{Tseng}, 1995)$ and at $-80{ }^{\circ} \mathrm{C}$ (Dekaris $\&$ Gabriæ, 2009), but our objective was to evaluate the microbiological efficiency of glycerin $99 \%$ in preserving the tissue at room temperature. A number of authors found that glycerin in association with a cell culture medium MEM (Minimal Essential Medium), at $-80^{\circ} \mathrm{C}$, acted to guarantee the tissue integrity and the preservation of growth factors and cytokines in human amniotic membrane (Pena et al., 2007), but others concluded that glycerin used as a cryoprotectant may impair the function of human amniotic membrane as a substrate for limbus cell culture (Shortt et al., 2008). Thus, the other effects that glycerin $99 \%$ used as storage medium can cause in the amniotic membrane is still controversial.

Because our group frequently uses the amniotic membrane in research and in the hospital routine (Pontes et al., 2011; Pontes et al., 2014), it was important to evaluate this medium aiming at creating a bank of this tissue to be used in the long term.

Some other factors were also taken into account to evaluate glycerin $99 \%$ as a preservation medium, including low cost and easy handling (Pigossi, 1967; Amendola, 2007; Pontes et al., 2011; Pontes et al., 2014) and acquisition (Pontes et al., 2008), as well as abolishing other high-cost media of difficult transportation (Alvarenga, 1992) such as keeping at $-80^{\circ} \mathrm{C}$.

The ability of glycerin $99 \%$ to act against some specific bacterium and fungus was not evaluated, since it was not the objective of this study. However, some studies have confirmed its bactericidal action on Staphylococcus aureus, Streptococcus faecalis, Escherichia coli and Pseudomonas aeruginos and its inability to prevent the growth of Clostridium botulinium and Clostridium perfringes (Pigossi et al., 1971; Amendola, 2007). Other studies reported that glycerin has no action on some more resistant sporulated forms (Pigossi et al., 1971) or viruses (Coronado et al., 1998), while some authors reported that glycerin is only effective against type I herpes virus and poliovirus when at $98 \%$ (Marshall et al., 1995). The same authors stated that to be effective against these viruses, the tissue must be maintained in $98 \%$ glycerin for at least 4 weeks at up to $20^{\circ} \mathrm{C}$.

As sterility maintenance is a primary concern in any conservation method (Slatter \& Dietrich, 2007), several media have already been analyzed for the preservation of biological membranes, including glutaraldehyde (Rabelo et al., 2004; Khor, 1997; Oliveira et al., 2009), 300\% glucose solutions (Oliveira et al., 2009; Brun et al., 2002b; Melo Filho et al., 2011; Vidor, 2012), and 5\% polyvinylpyrrolidone (Mota et al., 2002), which presented advantages and disadvantages.

By analyzing the various media and methods of preservation for biological material in the literature, it can be suggested that glycerin $99 \%$, at room

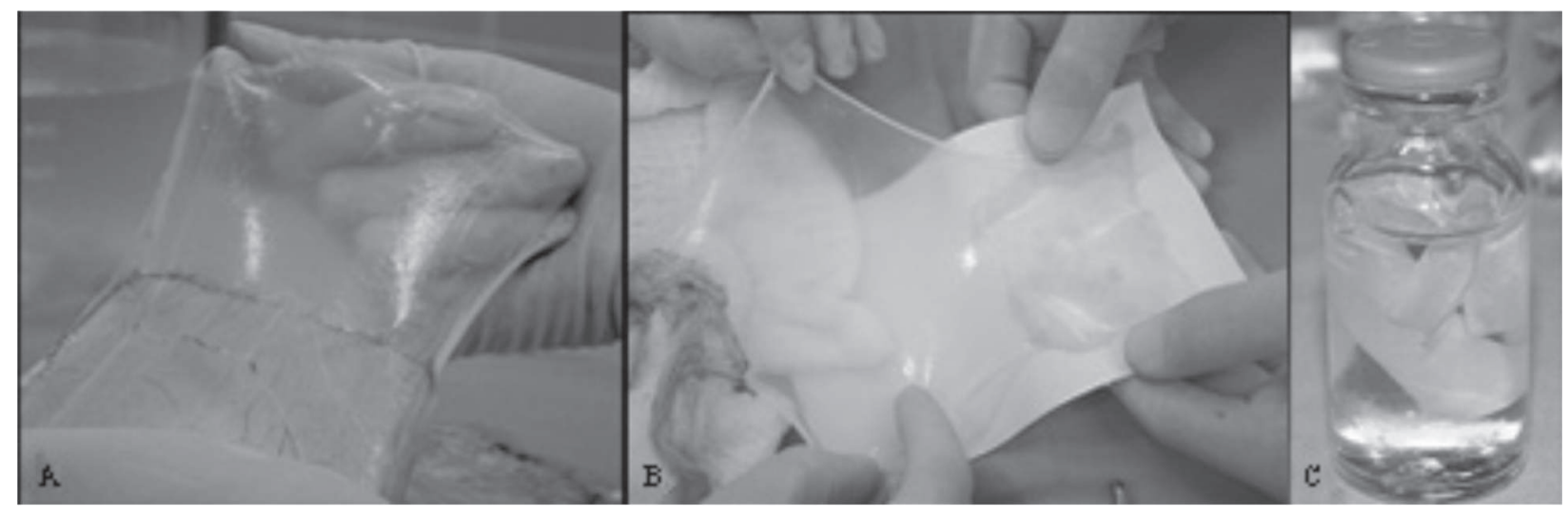

Figure 1: Pictures showing bovine amniotic membrane preparation. A - Amnion being manually separated from the chorion. B Amniotic membrane spreading onto nitrocellulose paper with epithelial face upwards. C - Amniotic membrane fragments in a flask containing sterile glycerin $99 \%$ to be stored at room temperature. 
temperature, shows greater advantages when used to store the bovine amniotic membrane under the described conditions. This finding makes it an ideal medium to be used in the creation of a bank of this type of membrane, with the possibility of its microbiological conservation at room temperature for long periods. This fact may facilitate the use of bovine amniotic membrane in the hospital routine, since it is a biomaterial of easy acquisition and handling, reducing discarding because of the impossibility of using it in fresh.

\section{CONCLUSIONS}

Glycerin $99 \%$ is an efficient preservation medium for bovine amniotic membrane previously prepared as described, with respect to microbiology, keeping the tissue free of microorganism growth in the media kept at room temperature for up to 48 months.

\section{ACKNOWLEGEMENTS}

The authors want to thank the Núcleo de Pesquisa e Extensão (NUPEX) of the Faculdade de Ciências Biológicas e da Saúde (FACISA/ UNIVIÇOSA), the Universidade Federal de Viçosa (UFV), Ophthalmos Indústria Farmacêutica, the Fundação de Amparo a Pesquisa do Estado de Minas Gerais (FAPEMIG), Conselho Nacional de Desenvolvimento Científico e Tecnológio (CNPq) and the Coordenação de Aperfeiçoamento de Pessoal de Nível Superior (CAPES) for the support granted.

\section{REFERENCES}

Alvarenga J (1992) Possibilidades e limitações da utilização de membranas biológicas preservadas em cirurgia. In: Daleck CR, Baptista LC \& Mukai LS (Eds). Tópicos em cirurgia de cães e gatos. Jaboticabal, Universidade Estadual Paulista. p.33-42.

Amendola GF (2007) Aspectos biomecânicos, bacteriológicos e micológicos de diáfises femorais caninas conservadas em glicerina a $98 \%$ ou mel. Tese de Doutorado. Universidade Federal de Santa Maria, Santa Maria. 100p.

Barros PS, Safatle AM, Godoy CA, Souza MS, Barros LF \& Brooks DE (2005) Amniotic membrane transplantation for the reconstruction of the ocular surface in three cases. Veterinary Ophthalmology, 8:189-192.

Barros PSM, Garcia JA, Laus JL, Ferreira AL \& Gomes TLS (1998) The use of xenologous amniotic membrane to repair canine corneal perforation created by penetrating keratectomy. Veterinary Ophthalmology, 1:119-123.

Brun MV, Pigatto JAT, Driemeier D, Oliveira LO, Beck CAC, Aguiar EV, Freire CD \& Gaiga LH (2002a) Traqueoplastia em cães com pericárdio equino conservado em glicerina por um período de 11 anos. Revista da FZVA, 9:113-142.

Brun MV, Pippi NL, Driemeier D, Contensini EA, Beck CAC, Cunha O, Pinto Filho ST, Roeshing C \& Stedile R (2002b) Solução hipersaturada de sal como conservante de pericárdio canino utilizado na reparação do músculo reto abdominal de ratos Wistar. Ciência Rural, 32:1019-1025.
Chirife J, Scarmato GA \& Herxzage L (1982) Scientific basis for use or granulated sugar in treatment of infected wounds. The Lancet, 1:560-561.

Choi JA, Choi JS \& Joo CK (2011) Effects of amniotic membrane suspension in the rat alkali burn model. Molecular Vision, 17:404-412.

Coronado Jr. GS, Martinez SA \& Swenson CL (1998) Virucidal and osteogenic effects of $98 \%$ glycerol and ethylene oxide preservation of bone allograft in the cat. In: Annual Conference of Veterinary Orthopedic Society, Colorado. Anais, Veterinary Orthopedics Society. p.31.

Costa Neto JM, Daleck CR, Alessi AC \& Braccialli CS (1999) Tenoplastia experimental do calcâneo em cães com peritônio bovino conservado em glicerina. Ciência Rural, 29:697-703.

Cremonini DN, Ranzani JJT, Marques MEA, Rodrigues GN \& Brandão CVS (2007) Transplante de membrana amniótica canina criopreservada para cicatrização de córnea com deficiência de células límbicas em coelhos. Arquivo Brasileiro de Medicina Veterinária e Zootecnia, 59:1462-1467.

Daleck CR, Daleck CLM, Padilha Filho JG \& Costa-Neto JM (1992) Reparação de hérnia perineal em cães com peritônio bovino conservado em glicerina. Ciência Rural, 22:179-183.

Dekaris I \& Gabriæ N (2009) Preparation and preservation of amniotic membrane. Developments in Ophthalmology, 43:97-104.

Gioso MA, Benites NR \& Kämpf G (2002) Análise microbiológica de ossos de cães conservados por longo período de tempo na glicerina a $98 \%$ à temperatura ambiente, objetivando a enxertia óssea. Acta Cirúrgica Brasileira, 17:242-246.

Khor E (1997) Methods for the treatments of collagenous tissues for bioprostheses. Biomaterials, 18:95-105.

Kim JC \& Tseng SCG (1995) Transplantation of preserved human amniotic membrane for surface reconstruction in severely damaged rabbit corneas. Cornea, 14:473-484.

Krauspenhar LC (2003) Viabilidade bacteriana no meio de conservação glicerina $98 \%$ do tendão calcâneo comum. Dissertação de Mestrado. Universidade Federal de Santa Maria, Santa Maria. 62p.

Marshall L, Ghosh MM, Boyce SG, MacNeil S, Freedlander E \& Kudesia G (1995) Effect of glycerol on intracellular vírus survival: implications for the clinical use of glycerol-preserved cadaver skin. Burns, 21:356-361.

Melo Filho EV, Lúcia RM, Salgado AEP, Miranda FB, Drago MA, Taffarel MO, Vilela LM, Mussi JMS, Santos WG, Zanini MS \& Freitas PMC (2011) Mecânica e microbiologia de placas produzidas a partir de osso cortical bovino, conservados e diferentes meios. Ciência Rural, 14:660-666.

Mota FCD, Eurides D, Beletti ME, Freitas PMC, Mastrantonio EC, Shimizu BJ \& Martins AK (2002) Análise ultra-estrutural da túnica muscular de intestino delgado de cães preservado em diferentes meios. Brazilian Journalof Veterinary Research and Animal Science, 39:13-17.

Okamoto T, Kira ME, Okamoto R, Junior IRG \& Niccoli Filho WD (2000) Homogenous implant in rat tibias of matrix preserved in $98 \%$ glycerin: histomorphologic study. Brazilian Dental Journal, 2:79-87.

Oliveira L, Souza D, Abílio E \& Carvalho E (2009) Métodos de preservação de membranas biológicas para uso cirúrgico. Jornal Brasileiro de Ciência Animal, 2:175-188.

Pena JDO, Melo JB, Gomes JAP, Haapalainen EF, Komagome CM, Santos NC, Filho AASL \& Rizzo LV (2007) Ultrastructural and growth factor analysis of amniotic membrane preserved by different methods for ocular surgery. Arquivo Brasileiro de Oftalmologia, 70:756-762. 
Pigossi N (1967) A glicerina na conservação de dura-máter. Tese de Doutorado. Faculdade de Medicina de São Paulo, São Paulo. 36p

Pigossi N, Raia A, Lex A, Gama AH, Simonse O, Haddad J \& Tenuto R (1971) Estudo experimental e clínico sobre o emprego, como implante, da dura-máter homógena conservada em glicerina à temperatura ambiente. Revista da Associação Médica Brasileira, 17:263-78.

Pontes KCS, Borges AP, Duarte TS, Morato GL, Zavan V, Eleotério RB \& Carlo EC (2008) Membrana amniótica canina utilizada como bandagem em úlcera superficial de córnea de coelhos Aspectos clínicos. Arquivo Brasileiro de Medicina Veterinária e Zootecnia, 60:1069-1074.

Pontes KCS, Duarte TS, Machado DPD, Sepúlveda RV, Ramos DR \& Borges APB (2010) Membrana amniótica bovina, preservada em glicerina, no tratamento de úlcera de córnea em um cão e de sequestro corneal em dois felinos - relato de casos. Revista Clínica Veterinária, 85:88-96.

Pontes KCS, Borges AP, Eleotério RB, Favarato LSC \& Duarte TS (2011) Processo de reparação de lesões de córnea e a membrana amniótica na oftalmologia. Ciência Rural, 41:2120-2127.

Pontes KCS, Borges APB, Eleotério RB, Frazão ACN, Machado DPD, Reis ECC, Sepúlveda RV, Duarte TS \& Laus JL (2014) A new surgical technique to treat corneal perfurations using amniotic membrane and surgical adhesive. Arquivo Brasileiro de Medicina Veterinária e Zootecnia, 66:655-664.
Quinn PJ, Markey BK, Carter ME, Donelly WJ \& Leonard FC (2005) Microbiologia Veterinária e Doenças Infecciosas. Porto Alegre, Artmed. 512p.

Rabelo RE, Tavares GA, Paulo NM, da Silva LAF, Damasceno AD, Andrade MA, Martins FG, Romani AF, da Silva OC \& Trindade BR (2004) Características físicas e microbiológicas do centro tendíneo diafragmático ovino conservado em glicerina a $98 \%$ e no glutaraldeído a 4\%. Ciência Animal Brasileira, 5:229238.

Rios PSB, Pontes KCS, Borges APB, Silva GMM \& Machado JP (2014) Membrana amniótica bovina, conservada em glicerina, na reparação de córnea após ressecção de tumor dermóide em um cão - Relato de Caso. Revista Clínica Veterinária, 109:5866.

Shortt AJ, Secker GA, Lomas RJ, Wilshaw SP, Kearney JN, Tuft SJ \& Daniels JT (2008) The effect of amniotic membrane preparation method on its ability to serve as a substrate for the ex-vivo expansion of limbal epithelial cells. Biomaterials, 30:1056-65.

Slatter D \& Dietrich U (2007) Córnea e Esclera. In: Slatter D (Ed.) Manual de cirurgia de pequenos animais. $3^{a}$ edição. São Paulo, Manole. p.1368-1395.

Vidor SB (2012) Utilização de membranas descelularizadas associadas à terapia celular no reparo de hérnias incisionais em pequenos animais. Monografia. Universidade Federal do Rio Grande do Sul, Porto Alegre. 60p. 